\title{
Agenda Setting in the German Bundestag: A Weak Government in a Consensus Democracy
}

\author{
ULRICH SIEBERER
}

\begin{abstract}
Government agenda-setting rights in the Bundestag are weak. The theoretical part of this article discusses various aspects of agenda setting and their theoretical relevance in the context of the Bundestag. It will be argued that analyses of agenda setting should distinguish between two analytical foci, one concentrating on policy effects in the context of spatial models, the other analysing executive legislative relations in the broader context of political competition. In addition, agenda setting among veto players should be distinguished from agenda setting between veto players and non-veto players. While the article's theoretical part drives the subsequent empirical analysis, readers more interested in the empirical aspects of agenda setting in the Bundestag may wish to turn directly to the article's second section, which provides an empirical and descriptive account of the formal rules of agenda setting in the Bundestag. In this part, it will be argued that the weakness of the government under the Bundestag's first permanent rules of procedure introduced in the early 1950 s can be explained by historic circumstances. Since then, party system characteristics and the strong role of the Bundesrat have made it unattractive for the federal government to seek increased agenda control in the Bundestag. Overall, agenda setting rules in the Bundestag underscore the characterisation of Germany as a consensus democracy.
\end{abstract}

The study of parliaments has received increased attention with the growth of the neoinstitutionalist paradigm in comparative politics. In line with the claim that institutions have important consequences for both the processes and outcomes of political decisionmaking, the literature has analysed a variety of institutional structures and rules governing parliamentary decision-making. In this context, agenda setting rules are considered highly important in theoretical terms and have also received increased empirical attention.

From a theoretical perspective, agenda setting was originally discussed as a stabilising force in processes governed by majority rule and thus prone to the well-known cycling problems. ${ }^{1}$ More recently, agenda setting has become a major component of Tsebelis' veto player theory. Within this theory, agenda setting plays at least two distinct roles: it allows more precise predictions of policy outputs and it serves as an indicator for executive dominance more broadly. ${ }^{2}$ A second distinction implicit in 
Tsebelis' work, but so far neglected in the literature concerns the actors whose interactions are analysed: agenda setting can take place among veto players or between veto players and non-veto players. While the first directly relates to policy effects, the second speaks to the relationship between the governing majority and the opposition within the broader context of political competition. The following section deals with these distinctions in more detail.

The empirical study of agenda setting in parliaments originated in the context of the US Congress. Since the 1990s, case studies and comparative research have increasingly focused on parliamentary systems of government, asking which institutional rules allow the executive (the 'government' in European parlance) to shape the parliamentary agenda. Among European countries, France has gained particular attention due to the extraordinarily strong position of the government vis-à-vis the National Assembly. ${ }^{3}$

The theoretical importance of agenda setting warrants analysis of less studied countries as well. This article deals with the rules of agenda setting in Germany. Despite the extensive literature on the Bundestag as institution, few studies have focused on its agenda setting rules in detail. ${ }^{4}$ Judging from the only available broad comparative study on agenda setting by Herbert Döring, the German government seems neither particularly strong nor excessively weak, ranking somewhat below the average of 18 Western European countries. ${ }^{5}$

Döring's study analyses only one aspect of agenda setting. The third section of this article offers a more comprehensive descriptive account of agenda setting rules in Germany. This account reveals the institutional position of the German government as extremely weak; the legislative process is controlled almost entirely from within the Bundestag. The fourth section explains this weak position based on historical circumstances and analytical arguments. In historical perspective, German parliamentary procedures are highly path-dependent; they still exhibit characteristics from the time when the main line of confrontation ran between the government and parliament as a whole. This traditional separation of powers perspective and the fear of a dominant executive were important in the perception of political actors when designed the position of the Bundestag in the constitutional framework in 1948/49 and its first permanent rules of procedure in 1951. Two analytical arguments explain why no government saw the need to push for increased agenda setting rights over the history of the Federal Republic. First, party system characteristics led to stable majority coalitions that could control legislative business from within the Bundestag. Second, the Bundesrat, as an additional institutional veto player, decreases the value of controlling the parliamentary agenda.

The article's penultimate section discusses the author's findings under different theoretical perspectives. With regard to analysing direct policy effects, the article identifies two additional themes that would have to be studied in detail: agenda setting in the cabinet (about which we know little) and agenda setting in the Mediation Committee (Vermittlungsausschuss) of Bundestag and Bundesrat (where the government is weak). With regard to executive dominance, agenda setting in the Bundestag reveals a very weak position of the executive branch and serious limits on the power of the parliamentary majority. These findings underscore the characterisation of Germany as a consensus democracy. 


\section{Theoretical Perspectives: What Does Agenda Setting Tell Us?}

We can order existing rational choice scholarship on agenda setting along two dimensions. ${ }^{6}$ The first dimension concerns the author's analytical focus. We can distinguish studies mainly interested in direct policy effects from those concerned with executive legislative relations more broadly. Along the second dimension, we ask which actors are analysed in studies dealing with agenda setting and either restrict our analysis to veto players or include non-veto players as well.

The first analytical focus derives from spatial models and considers agenda setting as a solution to the problem that policy making models under majority rule seldom propose one particular output. Instead they predict only a set of options. ${ }^{7}$ In the context of veto player theory, this perspective implies that a veto player who is able to set the agenda can exercise stronger influence over outputs. If a variety of solutions are acceptable to all actors whose consent is required, an agenda setter can pick which of those solutions is chosen. In the terminology of spatial models, the agenda setter can propose her preferred option from within the winset of the status quo. ${ }^{8}$ The agenda setter's advantage increases with the size of the winset, that is, agenda setting power is more valuable with regard to policies the more options all veto players would be willing to accept. The size of the winset itself depends on the number of veto players, their ideological distances, and the position of the status quo. ${ }^{9}$

The second analytical focus is concerned with the distribution of power between the executive and legislative branches more generally. A government with strong agenda setting prerogatives is dominant vis-à-vis parliament because it can 'have its proposals accepted the way they are as opposed to having them massively amended by parliament'. ${ }^{10}$ Thus, agenda setting rights can be used as indicators for executive dominance. ${ }^{11}$ This perspective is particularly interesting for empirical democratic theory because we still lack satisfactory institutional indicators for executive dominance, forcing researchers to rely on behavioural proxies such as the average duration of a cabinet instead. ${ }^{12}$ While many commentators criticise cabinet duration as a rather imperfect approximation of executive dominance, no superior alternative has thus far been suggested. A systematic comparative analysis of government agenda setting rights may offer such an alternative.

As a second dimension, we can distinguish two answers to the question of which actors have to be analysed in studies on agenda setting. The first group of studies restricts its attention to agenda setting among veto players whereas the second group analyses agenda setting between veto players and non-veto players. This distinction is not stated explicitly in Tsebelis' work, but results directly from the two analytical foci discussed above. By definition, only veto players influence policy outputs in the veto player framework. Thus, only agenda setting among them can have direct policy consequences. Discussions of executive legislative relations in parliamentary systems, on the other hand, are vitally concerned with the relationship between veto players, that is, governing parties, and non-veto players, that is, opposition parties. We will see, though, that the two dimensions cannot be reduced to one because studying agenda setting between veto players alone can tell us something important about 
executive legislative relations and because agenda setting towards non-veto players can have policy effects. Therefore, we are dealing with a truly two-dimensional framework.

Combining these two dimensions allows us to differentiate between four theoretical perspectives on agenda setting in the literature. For each perspective, we can identify one overarching research question (see Table 1).

When our analytical focus stresses direct policy effects and only agenda setting among veto players is analysed (cell I), the resulting research question is which veto player can exert disproportionate influence on policy outputs by using agenda setting instruments. This type of research includes classic work on agenda setting in the context of spatial models. ${ }^{13}$ Work on agenda setting within coalition cabinets also fits into this cell. ${ }^{14}$

When we shift our analytical focus to executive legislative relations more broadly while still analysing only the interaction among veto players (cell II), the main question becomes how the government is able to achieve its interests against its own parliamentary parties. This question only becomes relevant when we allow government ministers and MPs of the same party to have different preferences and thus give up the unitary actor assumption frequently found in the literature. This cell is the realm of principal agent $(\mathrm{P} A)$ theory as applied to the study of parliaments. ${ }^{15}$

TABLE 1

FOUR THEORETICAL PERSPECTIVES ON AGENDA SETTING IN THE LITERATURE

\begin{tabular}{|c|c|c|}
\hline \multirow[b]{2}{*}{ Array of actors analysed } & \multicolumn{2}{|c|}{ Analytical focus } \\
\hline & Direct policy effect & $\begin{array}{c}\text { Broader executive-legislative } \\
\text { relations }\end{array}$ \\
\hline \multirow[t]{2}{*}{ Only veto players } & I & II \\
\hline & $\begin{array}{l}\text { Which veto player can determine } \\
\text { which alternative is chosen from } \\
\text { the winset of the status quo? } \\
\text { - Tsebelis } 2002 \text {, ch. } 1 \\
\text { - agenda setting in spatial } \\
\text { models } \\
\text { - literature on coalition } \\
\text { governance }\end{array}$ & $\begin{array}{l}\text { How can the government } \\
\text { defend its priorities vis à vis } \\
\text { its own MPs and ensure party } \\
\text { unity? } \\
\text { - P A literature allowing for } \\
\text { divergent interests between } \\
\text { ministers and government } \\
\text { MPs, e.g. } \\
\text { - Strøm/Müller/Bergman } 2003 \\
\text { - Diermeier/Feddersen } 1998\end{array}$ \\
\hline $\begin{array}{l}\text { Veto players and non veto } \\
\text { players }\end{array}$ & $\begin{array}{l}\text { III } \\
\text { How can veto players avoid } \\
\text { making policy concessions to } \\
\text { non veto players in pursuit of } \\
\text { non policy goals, especially } \\
\text { future electoral success? } \\
\text { Tsebelis } 2002 \text {, ch. } 4 \text { [implicit } \\
\text { in the discussion of minority } \\
\text { governments] } \\
\text { - Döring } 1995\end{array}$ & $\begin{array}{l}\text { IV } \\
\text { (How) can the government and/or } \\
\text { the governing parties dominate the } \\
\text { opposition in parliamentary } \\
\text { business? } \\
\text { - Tsebelis 2002, ch. } 4 \\
\text { [discussing Lijphart] } \\
\text { - Powell } 2000\end{array}$ \\
\hline
\end{tabular}

Note: Full bibliographic information on the cited literature is given in the relevant notes (No.13 18). 
Studies grouped in cell III are interested in direct policy effects of agenda setting, but include non-veto players in the analysis. The main question is how veto players can use agenda setting instruments to avoid the need to compromise with non-veto players. As will be discussed in more detail below, this question only becomes relevant when goals other than policy are introduced into the motives of political actors.

Finally, scholarship can focus on the broader impact of agenda setting on executive legislative relations and analyse both veto players and non-veto players (cell IV). Here, the main research questions relate to the interaction of government and opposition parties in the context of political competition more generally.

Tsebelis' veto player theory mainly deals with cells I and IV. His theoretical argument in chapter 1 uses the perspective of cell I a veto player with agenda setting power can determine which policy alternative is chosen from the winset. Tsebelis' argument on executive dominance in relation to Lijphart's Patterns of Democracy falls into cell IV. He focuses on agenda setting rights of veto players (the government and its parliamentary parties) against non-veto players (opposition parties), and his argument deals with political competition in a broader context. ${ }^{16}$

What about the other two perspectives on agenda setting? Cell II is not relevant for Tsebelis because he assumes parties in parliamentary systems to behave as unitary actors, regardless of whether members of a party hold government office or a seat in parliament. ${ }^{17}$ Literature in cell II rejects this assumption and deals explicitly with divergent interests between government members and their parliamentary parties. Different interests may come from different views on policy questions, from electoral fears particularly of backbenchers, or from office goals of ministers.

Tsebelis touches on cell III in his argument about the importance of agenda setting for the viability of minority governments. He does not count non-government parties under minority governments as veto players. Thus, agenda setting takes place between veto players and non-veto players. Tsebelis argues that agenda-setting rights are particularly important for minority governments to avoid legislative defeats and pass legislative proposals. This focus is in line with the main research question identified for the type of studies in cell III.

For majority governments, on the other hand, cell III is irrelevant under a strict reading of veto player theory. As the theory is static and assumes sincere voting, nonveto players only interested in policy know that their consent is not required for passing bills and should thus simply back down. The theory can be extended, though, by introducing time and future electoral success as relevant resources. If policy blockades will be blamed mainly on the government, opposition parties hoping for future electoral payoffs may choose to obstruct parliamentary business. Governments, on the other hand, may be willing to make policy concessions to non-veto players in order to speed up business and present results to the public. In short, smooth parliamentary passage is traded against policy concessions. ${ }^{18}$ Under such an extended version of veto player theory, agenda setting rights vis-à-vis non-veto players are indeed relevant for policy outputs as they allow governments to avoid such concessions.

A few clarifications are necessary with regard to the distinctions introduced above. First, the different perspectives in the literature are complementary. Accordingly, particular agenda setting instruments may be relevant in more than one of the cells 
discussed above. Second, distinguishing between the analytical focus on policy effects and executive legislative relations more broadly does not refute the idea that executive dominance may have policy effects. ${ }^{19}$ Nonetheless, studies with the second focus are mainly interested in patterns of political competition and questions of the representation of interests. Third, the very term 'executive legislative relations' is ambiguous. Taken literally, the term relies on the classic separation of powers view, which conceptualises government and parliament as generally opposed institutions. This perspective is not very useful for understanding contemporary parliamentary systems of government. ${ }^{20}$ In general, these systems are characterised by the confrontation between the government and its parliamentary parties on the one hand and opposition parties on the other hand. Under this perspective, agenda setting rights of the executive and of parliamentary majorities have to be analysed together. ${ }^{21}$

This article uses both readings of 'executive legislative relations' and discusses rights that are particularly given to the executive as well as rights of the parliamentary majority. The first set of prerogatives is useful for government members having different interests from their parliamentary parties, whereas the latter mainly applies to the conflict between the governing majority and the opposition. Empirically, the main focus of this article is on agenda setting rules in the plenary of the Bundestag. ${ }^{22}$ As will become clear in the discussion, these rules speak primarily to the broader executive legislative relations perspective. A study focusing on direct policy effects of agenda setting in Germany would have to include additional arenas, in particular the cabinet and the Mediation Committee of the Bundestag and the Bundesrat. Relevant aspects for further investigation will be discussed at the end of the article.

\section{Empirical Perspectives: Agenda Setting Instruments}

Agenda setting comprises a variety of different instruments. Before analysing these instruments in the German case, they have to be ordered systematically. Herbert Döring proposes distinguishing three aspects:

(1) setting the topical agenda, that is, determining the content of public debate;

(2) setting the voting agenda, that is, controlling what bills and amendments come to be voted on in parliament; and

(3) setting the timetable agenda, that is, determining the length of parliamentary debate and the timing of voting. ${ }^{23}$

In pluralist democracies, the topical agenda is largely out of the reach of political actors as interest groups and the media play major roles alongside and in interaction with political parties and elected officials. Therefore, this aspect of agenda setting is not dealt with here. ${ }^{24}$

Agenda setting with regard to the voting agenda speaks most directly to the question of policy effects. It deals with the general scope of legislative versus executive lawmaking authority, negative agenda control, the right to initiate bills and offer amendments, rules concerning the content of bills and the admissibility of amendments (such as closed rules and the germaneness rule), and the link between policy decisions and votes of confidence in the government. 
Agenda setting with regard to the timetable agenda refers most directly to the nature of executive legislative relations and the relationship between governing and opposition parties (cell IV in Table 1). It only gains relevance for policy outputs when negotiations in parliaments are conceptualised as a game in which opposition parties (and possibly government backbenchers) can extract policy concessions from the government in exchange for foregoing obstruction (cell III). Therefore, it is problematic to use timetable control as a proxy for agenda-setting powers with regard to the voting agenda within a temporarily static theory (cell I), as Tsebelis does in his veto player theory. ${ }^{25}$ Relevant rules of timetable agenda setting include arranging the plenary agenda and ending or restricting debate. ${ }^{26}$

\section{AGENDA SETTING IN THE BUNDESTAG: PROCEDURAL DUALISM IN A PARTY CENTRED PARLIAMENT}

\section{The Bundestag in the German Political System}

Before discussing agenda setting in the Bundestag in more detail, a few general remarks on the organisation of the Bundestag and its position in the German political system are necessary. First, the Bundestag is not the only chamber involved in German lawmaking. The Bundesrat, a second chamber consisting of delegates from the state governments, becomes an additional institutional veto player for most important bills. ${ }^{27}$ During about half of the period since 1970, the parties forming the federal government did not hold a majority in the Bundesrat so that the latter was not absorbed as veto player. ${ }^{28}$

Second, the Bundestag comes closer to a working assembly than to a British-style talking assembly as most substantive legislative work is done in the standing committees. ${ }^{29}$ Third, procedures in the Bundestag are mainly structured by parliamentary party groups (PPG; Fraktion in German) whose dominance has increased over the history of the Federal Republic. This is reflected in the rules of procedures which give the PPGs an exalted procedural position as compared to individual MPs or groups of MPs without PPG status such as inter-partisan initiatives. ${ }^{30}$

Fourth, the Council of Elders (Ältestenrat) plays an important role as the main coordinating body of the Bundestag. ${ }^{31}$ It consists of the president of the Bundestag, his or her deputies, and 23 MPs delegated by the party groups in proportion to their size. As the Council is not a formal decision-making body, agreements can only be reached unanimously. If no agreement is reached, majority decision in the plenary usually serves as the fallback option.

Fifth, the legal foundations of German parliamentary procedures display a surprising pattern of continuity since the middle of the nineteenth century despite the fundamentally different character of the regimes in which the various parliaments acted. ${ }^{32}$ The current rules of procedure of the Bundestag (Geschäftsordnung des Deutschen Bundestages, hereafter GOBT) can be traced back to the rules of the Prussian Chamber of Deputies from 1849 and their subsequent adaptations in the North German Federation of 1867, the German Empire of 1871, and the Weimar Republic from 1918 to 1933 . In 1949, the Bundestag returned temporarily to the 1923 rules with some provisions changed to comply with regulations of the Basic Law (such as the election of the Chancellor). The Bundestag's first permanent rules of procedure were 
worked out in 1951 and became operative in 1952. Even with some 30 changes, the structure of the 1951 rules clearly remained in the tradition of its Weimar predecessor. Major reforms of the rules of procedure took place in 1969/70 and 1980 (including a new numbering of the paragraphs). In addition, some 40 minor changes and additions were included over the history of the Federal Republic. ${ }^{33}$ Overall, commentators of German parliamentary law describe these reforms as cautious modifications rather than radical changes. ${ }^{34}$

Given these historic continuities, it is hardly surprising that the rules of procedure are in many respects framed according to the traditional notion of separation of powers that conceptualises parliament and government as two distinct and generally opposed institutions. ${ }^{35}$ At the same time, some rules have been interpreted and changed (often much later) in the light of Germany's functioning as a parliamentary democracy in which the main line of conflict runs between governing and opposition parties. This is particularly clear with regard to the order of speakers and the allocation of speaking time: a member expressing a 'differing opinion', that is, a member of the opposition, shall speak directly after a member of government ( $\$ 28$ GOBT introduced in 1969), and a party expressing such a 'differing opinion' can demand additional speaking time if a government member speaks for more than 20 minutes ( $\$ 35$ GOBT introduced in 1980). Since 1972, speaking time of government members and members of the Bundesrat is included in the time allotted to the party to which the speaker belongs, even though this rule has not been formalised. These rules and conventions acknowledge that members of one party usually act as one group no matter whether they are formally members of the government, the Bundestag, or the Bundesrat.

\section{Agenda Setting Instruments in the Bundestag}

What is the position of the German government (both the executive and the parliamentary majority ${ }^{36}$ ) when it comes to agenda setting in the Bundestag? The following discussion focuses on institutional rules as set out in the Basic Law and the Rules of Procedure. These institutional rules constitute the formal constraints faced by political actors in the German system. They are also the rules analysed in rational choice theories of legislative decision making. In practice, these rules can be applied differently due to informal rules or established behavioural patterns. Thus, empirical studies of policy-making processes may find other forms of agenda setting that are not analysed here. In what follows, the reader should bear in mind that the focus is on formal rules and their likely consequences and the article's conclusions might have to be modified slightly when confronted with studies of policy-making processes in various policy fields. ${ }^{37}$ Rules about setting the voting agenda and setting the timetable agenda are discussed in turn.

The first element of government agenda control deals with the scope of legislative versus executive lawmaking, that is, with executive decree authority that allows the government to legislate without requiring a parliamentary vote. The main example among parliamentary democracies is the French Fifth Republic where parliament is barred from legislating in several policy areas reserved to executive decrees. ${ }^{38}$ The German executive has no such prerogatives. The Bundestag can delegate decree authority to the government, but only within clearly described limits and not on 'essential' decisions, especially those impinging on individual basic rights (Art. 80 Basic Law, 
hereafter GG). ${ }^{39}$ Neither can the government prevent the Bundestag from dealing with certain topics ('negative agenda control'). ${ }^{40}$

Second, the rights to initiate bills and offer amendments are important with regard to the voting agenda. Governments often enjoy exclusive rights to introduce bills pertaining to certain subjects, particularly money bills, and have special prerogatives in the amendment process. The most prominent instrument is the last-offer authority which allows the government to introduce the last amendment prior to the final voting on a bill. This right allows the government to counter amendments that were passed against its will. ${ }^{41}$ In Germany, the government, a majority in the Bundesrat, and PPGs or groups of at least 5 per cent of the members of the Bundestag (hereafter PPG/5 per cent) have the right to initiate bills (Art. 76 GG; $\$ 76$ GOBT). Only the right to initiating the annual budget bill is reserved to the government (Art. 110 III GG). This prerogative only refers to initiating the bill; the Bundestag is still free to amend it during the legislative process. Over the history of the Federal Republic, about 60 per cent of all bills were introduced by the government. ${ }^{42}$

The formal weakness of the executive is even more pronounced with regard to amendments: The government is not allowed to offer amendments in the Bundestag at all; amendments can only be proposed by individual MPs or PPGs. ${ }^{43}$ Accordingly, a special last-offer authority of the government cannot exist either. Once a bill is introduced, the government has to rely exclusively on its party groups to guide it through the legislative process. The position of the government is weakened further by the fact that Bundestag committees may and in fact do rewrite bills during the committee stage. ${ }^{44}$ If the Bundestag accepts a bill rewritten by a committee during the second reading, the government has no means to force a vote between the amended version and its original bill. At the same time it is important to bear in mind that, empirically, a large percentage of amendments during the committee stage refer to technical or wording questions and do not change the general outline of the bill. In addition, the governing parties coordinate their behaviour during the committee stage with the executive and many substantive changes in bills are initiated from within the governing parties with the consent of the government. ${ }^{45}$

Limits on the admissible content of bills and amendments are a third element of setting the voting agenda. Often deputies are not allowed to introduce bills or amendments with financial implications or such bills are subject to a government veto. ${ }^{46}$ In addition, amendments in many parliaments have to be related to the bill under discussion. This germaneness rule has gained particular attention in literature on the US Congress, but also exists in many European parliaments. ${ }^{47}$

In the German case, there are two limitations on the admissible content of bills and amendments. First, the government has the right to veto bills that would increase spending beyond the funds appropriated in the budget law or that would decrease revenue (Art. 113 GG, §87 GOBT). This rule was introduced in 1969 after the opposition and parts of the government parties had united to pass laws that increased spending. ${ }^{48}$ While the rule is rarely used today, it may be influential by way of anticipation. In order to avoid a direct involvement of the government, \$96 GOBT offers an alternative way to control excessive spending from within the Bundestag: if a bill has financial implications for the current or future budget laws, the Budget Committee has to propose ways to balance new expenses or decreased revenues. If no balancing solution 
is found by the committee, the plenary only decides on whether a balance in spending is possible. If not, the bill is considered to have failed and is not pursued further. ${ }^{49}$

Second, amendments have to relate to the original reasons or aims of the proposed bill. This germaneness rule is not formalised in the rules of procedure but goes back to a decision by the Bundestag's Rules Committee. If doubts occur as to whether an amendment is germane, the plenary decides by majority vote. ${ }^{50}$

Closed rules forbidding any amendment of a proposal by parliament are another particularly strong instrument of setting the voting agenda. While closed rules are highly relevant in the US Congress, they are less important in European parliaments where procedures are not set individually for each bill. The general rules of procedure include the right to offer amendments to bills under the limitations discussed above. Closed rules are thus mainly limited to non-legislative votes and votes on interchamber compromises in bicameral systems. In the Bundestag, amendments are forbidden on the ratification of international treaties, on executive decrees requiring the consent of the Bundestag, and on proposals by the Mediation Committee of the Bundestag and Bundesrat. ${ }^{51}$

Finally, governments can gain leverage on parliamentary votes by making their passage a matter of confidence. As Huber argues, using this procedure allows the government, more precisely the Prime Minister, to discipline the governing PPG(s) by increasing the stakes. Deputies no longer decide purely on policy terms, but have to consider the losses tied to government resignation and possibly to the dissolution of parliament. $^{52}$ As Heller points out though, using the vote of confidence is not without risks for the government, so that it is not an instrument to be used on a regular basis. ${ }^{53}$ Under the Basic Law (Art. 68, $81 \mathrm{GG}$ ), the chancellor can combine the vote on a bill with the vote of confidence. This weapon has been used only once, when Chancellor Schröder made the decision on sending military troops to Afghanistan a matter of confidence in November 2001.

The German version of the confidence vote is not particularly attractive for the government for two reasons. First, the government has to be supported by an absolute majority of all members of the Bundestag to win the vote, that is, abstentions count against the government (Art. $68 \mathrm{GG}){ }^{54}$ Second, the chancellor cannot dissolve the Bundestag at will after losing a confidence vote. Instead, he or she can only propose the dissolution which has to be decided by the President who is free in his decision. ${ }^{55}$ Even though the vote of confidence procedure has been used only once as an agenda setting instrument, ${ }^{56}$ it may have important anticipatory effects, and there is qualitative evidence that Chancellor Schröder used the threat to resign repeatedly in order to induce discipline from the governing parties. ${ }^{57}$

Finally there is the procedure for legislative emergency (Gesetzgebungsnotstand, Art. 81 GG), which has never been used and does not exert any discernible effects based on anticipation. ${ }^{58}$

Let us now turn to what Döring calls setting of the timetable agenda. The first question is simply who determines the plenary agenda. This can be the executive (as in Ireland or the UK with the exception of 'Opposition Days') or various actors within parliament, which can be ordered according to the influence exercised by the government parties. ${ }^{59}$ In the Bundestag, the agenda is usually set by unanimous agreement in the Council of Elders or, for details, through unanimous inter-partisan agreements 
between the party whips (parlamentarische Geschäftsführer) ( $\$ 20$ GOBT). Formally, the Council of Elders only proposes an agenda containing the points to be dealt with in a parliamentary sitting, their order, whether a debate should be held on each point and, if yes, its length, the number of speakers and the time allotted to the different PPGs. ${ }^{60}$ This proposal is considered approved if no objections are raised before the sitting starts. Alternatively, individual MPs can propose changes that are discussed and voted on under majority rule before the start of the sitting. ${ }^{61}$ Once the sitting convenes, any PPG/5 per cent can prevent the addition of new items to the agenda.

The executive branch does not participate in setting the plenary agenda. Usually a junior minister from the chancellor's office is present at meetings of the Council of Elders but has no say in decision making there. Thus government bills only get on the agenda if unanimous agreement is reached or if government PPGs pass a corresponding motion to change the agenda in the plenary. The only prerogative of the government is the right to be heard at any time (Art. 43 II GG), which does not include the right to offer bills or amendments.

How should we interpret the right of the parliamentary majority to set the plenary agenda by majority vote? On the one hand, this indicates a strong position of a majority government able to control its PPGs. ${ }^{62}$ On the other hand, several rules guarantee minority access to the agenda. For example, any PPG/5 per cent can demand that their motion is placed on the agenda when three weeks have elapsed since the motion's introduction in print, and any PPG/5 per cent can demand a one-hour topical debate on a current issue $\left(\S \S 20,106\right.$, Appendix 5 GOBT) ${ }^{63}$ Thus, the formal rules establish a rather balanced relationship between government and opposition parties, which may explain why plenary agenda setting usually takes place in a cooperative style. ${ }^{64}$ Motions to change the agenda are rare, indicating that compromises reached in the Council of Elders are either acceptable to all parties or that minority parties know that attempts to change the agenda are likely to fail. ${ }^{65}$

A second element of timetable agenda setting are rules for curtailing debate. Examples include the guillotine procedure, which sets a fixed time for voting on a bill regardless of whether all articles have been debated, and cloture, which ends debate on a particular article. ${ }^{66}$ The guillotine procedure is unknown in German parliamentary law, but debate on a particular clause can be ended by majority decision. Cloture can be invoked only after at least one speaker of each party had the opportunity to speak ( $\$ 25$ GOBT). Thus, even a determined majority is unable to avert critical comments by opposition parties. In practice, cloture has not played an important role in the Bundestag as speaking time is allotted consensually in the Council of Elders. $^{67}$

What is the overall picture with regard to government agenda control in the Bundestag? Table 2 summarises the instruments discussed above. The third column shows that explicit prerogatives of the executive are extremely rare. The only such instruments with regard to the voting agenda are the monopoly right to initiate the budget law, the (very rarely used) veto on money bills, and the closed rule on international treaties negotiated by the government and on executive decrees requiring parliamentary consent. ${ }^{68}$ In addition, the government has two very severe instruments at its disposal: combining a vote on a bill with the confidence procedure (used only once since 1949) and declaring legislative emergency under narrow conditions (never used). 
Looking at the timetable agenda, the only special prerogative of the government is the right to be heard at any time.

When we treat agenda setting rights of the parliamentary majority as government rights (fourth column), the picture does not change dramatically. With regard to the voting agenda, a parliamentary majority cannot control the agenda either. A unified majority can, of course, defeat initiatives and amendments from the opposition in voting, but it cannot prevent opposition parties from submitting motions and thus taking up precious plenary time. Nor can the majority use agenda setting rights to avoid taking a stand on issues. The position of the majority is somewhat stronger with regard to the timetable agenda as majority decision serves as the fallback option if no consensus is reached. On the other hand, the GOBT guarantees minority access to the agenda, with regard both to bills and topical debates. This balance provides strong incentives for compromise solutions in the Council of Elders or informal agreements among party whips. This tendency is strengthened further by the premium the Bundestag places on committee work and the relatively minor role of plenary debate. As the most important parliamentary work is not done in plenary sittings anyway, parties are reluctant to waste time and resources on disputes over the conduct of business and instead prefer to settle such matters in a pragmatic fashion.

\section{WHY IS THE GOVERNMENT'S POSITION SO WEAK?}

Parliamentary rules of procedure in Germany are historically rooted in the period of constitutional monarchy, when government and parliament were seen as separate and generally opposed institutions. The Weimar Constitution of 1919 installed a parliamentary system of government with a very strong president, often labelled as semi-presidential in the literature. It was not until after World War II that (West) Germany introduced an unambiguously parliamentary system of government. The question emerges why this change in regime type was not accompanied by a more radical re-writing of parliamentary rules that would have given the government specific institutional means for controlling the parliamentary agenda.

To answer this question it is useful to start from the more general question of why strong agenda setting powers of the government are introduced. Two answers come to mind: first, as in the UK, government prerogatives result from a historically developed complete fusion of government and parliamentary majority ${ }^{69}$ Second, as in the French Fifth Republic, government agenda setting powers are deliberately created to weaken a parliament that is considered responsible for government instability and/or incoherent policy decisions. ${ }^{70}$

When the Bundestag passed its first permanent rules of procedures in 1951, both of these motives were absent: despite the strictly parliamentary thrust of the Basic Law, the traditional view of the separation of powers was still popular Montesquieu, not Bagehot served as theoretical point of reference. ${ }^{71}$ This view is still present in the selfperception of deputies. When asked in a survey in 1989,39 per cent of the responding MPs stated they personally preferred a strict separation of powers system whereas only 34 per cent supported a dual model in which the government and its PPGs as one entity oppose the opposition parties. The remaining 27 per cent preferred a system in which the government, government PPGs, and opposition parties acted as three separate 


\begin{tabular}{|c|c|c|c|c|}
\hline $\begin{array}{l}\text { Agenda setting } \\
\text { instrument }\end{array}$ & Situation in the Bundestag & $\begin{array}{l}\text { Prerogative of } \\
\text { the executive } \\
\text { branch }\end{array}$ & $\begin{array}{l}\text { Control by } \\
\text { parliamentary } \\
\text { majority }\end{array}$ & $\begin{array}{l}\text { Legal source/source } \\
\text { in the literature }\end{array}$ \\
\hline \multicolumn{5}{|c|}{ Agenda setting with regard to the voting agenda } \\
\hline $\begin{array}{l}\text { Exclusive decree } \\
\text { authority }\end{array}$ & & No & No & Art. 80 I GG \\
\hline Negative agenda control & & No & No & \\
\hline Right to initiate bills & Government; Bundesrat; PPG or $5 \%$ of MPs & No & No & $\begin{array}{l}\text { Art. } 76 \text { I GG, §76 I } \\
\text { GOBT }\end{array}$ \\
\hline $\begin{array}{l}\text { Exclusive right to initiate } \\
\text { certain bills }\end{array}$ & $\begin{array}{l}\text { Government monopoly on initiating budget } \\
\text { law }\end{array}$ & Yes & No & Art. 110 III GG \\
\hline $\begin{array}{l}\text { Right to offer } \\
\text { amendments }\end{array}$ & $\begin{array}{l}\text { Individual MPs during } 2 \text { nd reading, PPG or } \\
5 \% \text { of MPs in } 3 \text { rd reading }\end{array}$ & No & No & $\S \S 82$ I,85 I GOBT \\
\hline Last offer authority & & No & No & \\
\hline Limits on individual bills & Limited to PPG or $5 \%$ of MPs & No & No & $\S 76$ I GOBT \\
\hline $\begin{array}{l}\text { Limits on individual } \\
\text { amendments }\end{array}$ & Only during 2nd reading & No & No & $\$ 82 \mathrm{I}, 85 \mathrm{I}$ GOBT \\
\hline Germaneness rule & $\begin{array}{l}\text { Only amendments with connection to the } \\
\text { original bill are admissible }\end{array}$ & No & No & Kabel 1989: 901 \\
\hline $\begin{array}{l}\text { Government veto on } \\
\text { money bills }\end{array}$ & $\begin{array}{l}\text { Government can veto bills that increase } \\
\text { expenditures or decrease revenues }\end{array}$ & Yes & No & $\begin{array}{l}\text { Art. } 113 \mathrm{GG}, \S 87 \\
\text { GOBT }\end{array}$ \\
\hline $\begin{array}{l}\text { Other limitations on } \\
\text { money bills }\end{array}$ & $\begin{array}{l}\text { Bills with considerable effects on public } \\
\text { finances that would impact on the current } \\
\text { budget law fail if no balancing solution is } \\
\text { found }\end{array}$ & No & Yes & $\$ 96$ GOBT \\
\hline Closed rule & $\begin{array}{l}\text { Only on (1) international treaties, }(2) \\
\text { proposals from the Mediation Committee, } \\
\text { and (3) executive decrees requiring } \\
\text { consent by the Bundestag }\end{array}$ & $\begin{array}{l}\text { (1) yes } \\
\text { (2) no } \\
\text { (3) yes }\end{array}$ & No & $\begin{array}{l}\$ 82 \text { II, } 90 \text { GOBT, } \S 10 \\
\text { GO VermA, Kabel } \\
\text { 1989: } 902\end{array}$ \\
\hline Confidence vote & $\begin{array}{l}\text { Chancellor can combine vote on a bill with a } \\
\text { vote of confidence }\end{array}$ & Yes & No & Art. 68,81 I GG \\
\hline
\end{tabular}


TABLE 2 (Cont'd)

\begin{tabular}{|c|c|c|c|c|}
\hline $\begin{array}{l}\text { Agenda setting } \\
\text { instrument }\end{array}$ & Situation in the Bundestag & $\begin{array}{l}\text { Prerogative of } \\
\text { the executive } \\
\text { branch }\end{array}$ & $\begin{array}{l}\text { Control by } \\
\text { parliamentary } \\
\text { majority }\end{array}$ & $\begin{array}{l}\text { Legal source/source } \\
\text { in the literature }\end{array}$ \\
\hline $\begin{array}{l}\text { Legislative emergency } \\
\text { Agenda setting with regar }\end{array}$ & $\begin{array}{l}\text { President can declare legislative emergency; } \\
\text { urgent bills can be passed solely with the } \\
\text { consent of the Bundesrat } \\
\text { timetable agenda }\end{array}$ & $\begin{array}{l}\text { Yes (consent of } \\
\text { President and } \\
\text { Bundesrat } \\
\text { required) }\end{array}$ & No & $\begin{array}{l}\text { Art. } 81 \mathrm{GG}, \S 99 \\
\text { GOBT }\end{array}$ \\
\hline Setting plenary timetable & $\begin{array}{l}\text { Unanimously in Council of Elders; can be } \\
\text { changed by majority decision; several } \\
\text { guaranteed minority rights }\end{array}$ & $\begin{array}{l}\text { No (only right to } \\
\text { be heard) }\end{array}$ & Only to limited extent & $\S 20 \mathrm{GOBT}$ \\
\hline Curtailing debate & $\begin{array}{l}\text { By majority rule after at least one speaker of } \\
\text { each PPG could speak }\end{array}$ & No & $\begin{array}{l}\text { Yes (after } 1 \text { speaker } \\
\text { per PPG) }\end{array}$ & $\S 25$ GOBT \\
\hline
\end{tabular}

Note: Sources in the literature are only listed if they contain information beyond the content of the cited legal norms. Additional literature is mentioned in the text. $\mathrm{GG}=$ Basic Law (Grundgesetz).

GOBT $=$ Rules of Procedure of the Bundestag (Geschäftsordnung des Deutschen Bundestages). 
entities. At the same time, 85 per cent of the deputies described the dual model as closest to the actual functioning of the Bundestag. ${ }^{72}$ While opposition members are generally more critical of the dual model than members of the governing parties, these numbers clearly indicate that in general German MPs are well aware of their role as parliamentarians and do not see themselves as mere agents of the government.

The second motive for granting governments agenda setting powers, that is, the urge to strengthen the executive against an encroaching parliament, was even more problematic in post-war Germany. Given the horrors of the Third Reich and the experience of unlimited executive rule in a totalitarian dictatorship, it is not surprising that the fathers of the Basic Law did not think of giving the executive particularly strong procedural powers. ${ }^{73}$ Instead, the Basic Law clearly states the primacy of the Bundestag as the only institution directly legitimated by the public. This primacy is expressed in such rules as the formal election of the chancellor, the constitutional limits on executive decrees, and the principle that 'essential' decisions on legislative issues may not be delegated to the executive. At the same time, the weak position of the government and the strong presidency under the Weimar Constitution were considered major defects of that system. As a consequence, the President was reduced to a foremost representative figure and the constructive vote of no-confidence was introduced in order to prevent majorities unable to agree on an alternative from bringing down a government. ${ }^{74}$ Granting specific institutional means of control over parliamentary business to an incumbent government was considered neither necessary nor given the then-recent experience of dictatorship desirable.

These historic circumstances explain why no clear break with earlier rules of procedures occurred in 1951. They do not explain, though, why the position of the government was not strengthened after the parliamentary system had taken root and the fear of executive dictatorship had receded. ${ }^{75}$ The absence of such reforms can be explained by analytical arguments about the basic characteristics of the party system and the broader institutional setting of the legislative process in Germany. Given these factors, strengthening government agenda setting rights was neither necessary nor promising from the view of political actors.

Three characteristics of the German party system are important in this respect. First, after a period of consolidation in the 1950s, only a small number of parties gained parliamentary representation. ${ }^{76}$ For over two decades, including the major rules changes in 1969/70 and 1980, only three PPGs (the CDU/CSU, SPD, and FDP) interacted in the Bundestag. Thus the bargaining environment was quite straightforward and predictable for the government. Second, PPGs usually behaved as unitary actors in parliamentary voting so that governments did not have to strive for instruments to discipline its own parties. ${ }^{77}$ Third, all non-transient governments after 1949 held a parliamentary majority and thus could use the means available to parliamentary majorities.

In addition to party system characteristics, the strong role of the Bundesrat in legislative decision-making is a crucial explanatory factor. Winning a vote in the Bundestag is often simply not enough to pass a bill, especially when the Bundesrat is controlled by different parties. But even if government parties hold a majority in the Bundesrat, the latter may not be absorbed as a veto player because state governments sometimes hold policy positions different from those of the federal parties 
and sometimes pursue state interests that do not align with partisan lines of conflict. ${ }^{78}$ In this setting, the value of agenda control in the Bundestag decreases. Even if the government were able to overplay the opposition or parts of the government parties in the Bundestag, these groups would still have the opportunity to veto the bill in the Bundesrat. If the Bundesrat does not pass the bill, the Mediation Committee of the two chambers is activated and attempts to reconcile the differences. In this process of finding an inter-chamber compromise any benefits the government could have drawn from using agenda setting prerogatives in the Bundestag are likely to be reversed. Proposals by the Mediation Committee are voted on under closed rule in both the Bundestag and the Bundesrat. Therefore, the government is unable to reclaim its original proposals after the mediation process.

Thus, this article offers two explanations for the institutionally weak position of the German government. First, the historic circumstances in the late 1940s and early 1950s prevented the political actors from granting the executive far-reaching agenda setting rights. Second, party system characteristics and the important role of the Bundesrat in the legislative process decreased the benefits that the executive could have drawn from increased agenda setting powers. Thus governments did not pursue this option even after the historic legacies had lost their constraining force.

\section{AGENDA SETTING IN GERMANY IN THE VIEW OF DIFFERENT THEORETICAL PERSPECTIVES}

Having described agenda setting rules in the Bundestag and explained the weak position of the executive, this article returns to the different theoretical perspectives outlined at the beginning and highlights, arenas that would have to be analysed in addition to the Bundestag.

Let us consider direct effects of agenda setting on policy outputs first. Under veto player theory in its present form (cell I in Table 1), only agenda setting among veto players is relevant. In Germany, agenda setting among veto players for the most part does not happen in the Bundestag. Instead, we have to investigate agenda setting within the executive and in the process of resolving conflicts between the government majority and an opposing majority in the Bundesrat.

As far as agenda setting within coalitions is concerned, the main assumptions in the literature are control by each minister of the policy dimensions in his or her portfolio ${ }^{79}$ and agenda setting by the prime minister. ${ }^{80}$ Tsebelis discusses and largely dismisses these alternatives and instead argues for a rather strong form of collective cabinet decision-making. ${ }^{81}$ He does not analyse agenda setting between governing parties empirically even though those usually make up all or at least the large majority of veto players in parliamentary systems. Additional theoretical and empirical study of intra-cabinet agenda setting would be necessary to make more specific predictions about which policies coalitions select from the array of alternatives that all coalition partners could agree on. ${ }^{82}$

Germany is often characterised as a 'chancellor democracy' indicating an extremely powerful position of the chancellor in the cabinet. ${ }^{83}$ The concept was mainly derived from the personal style of Konrad Adenauer and has been modified afterwards. ${ }^{84}$ Its value for describing executive decision making in Germany is debatable. 
Indeed the chancellor holds a strong position under the basic law: he or she is the only government member elected by the Bundestag and has the right to 'determine [...] the general guidelines of policy' (Art. $65 \mathrm{GG}$ ). At the same time, her role in determining policy is seriously limited by the fact that governments are always coalitions with rather elaborate written coalition agreements. In addition, the chancellor has to take interests from different intra-party groups into account. ${ }^{85} \mathrm{~A}$ majority of German ministers state that the chancellor does not have an important impact on overall government business and on particular policy fields with the exception of foreign policy. ${ }^{86}$ In view of these findings, 'chancellor democracy' seems to be more a bold aspiration than an accurate description of cabinet decision-making in Germany.

For most important bills, the majority of the Bundesrat is an additional veto player. In order to assess policy effects of agenda setting, we thus have to analyse how conflicts between the governing majority in the Bundestag and a differing majority in the Bundesrat are resolved. As discussed above, such conflicts are dealt with in the Mediation Committee consisting of 16 members of the Bundesrat (one per state) and an equal number of deputies from the Bundestag selected by the PPGs in proportion to PPG size. The Mediation Committee is very strong when compared to other conference committees in Western democracies, because its parent chambers place few restrictions on both the topics to be addressed and the possible contents of a compromise solution. ${ }^{87}$ The only limitation is that the compromise has to be accepted by majority vote in both chambers. As this vote is taken under closed rule though, the committee enjoys ample discretion on the details of the compromise as long as the final package is acceptable to both chambers or to use the language of spatial models is located within the winset of the status quo.

Agenda setting rights are not formalised in the Rules of Procedure of the Mediation Committee (Geschäftsordnung des Vermittlungsausschusses, GO-VermA). ${ }^{88}$ According to convention, every member of the committee can offer amendments. The order of voting is determined in analogy to the procedures in the Bundestag and Bundesrat. ${ }^{89}$ The government does not play a formal role in the Mediation Committee. A government member may be present ( $\$ 5 \mathrm{GO}-\mathrm{VermA})$, but can neither propose nor veto amendments or otherwise participate in voting. Therefore, the government does not have any institutional powers to influence the process of finding inter-chamber compromise. Instead, it has to rely completely on government MPs to pursue its interests.

Members of the Mediation Committee are handpicked by the PPG leadership and are thus more likely to serve as faithful agents of their parties. This implies that the collective party leadership in which government members play an important role can exercise indirect influence via the party members in the Mediation Committee as well. Therefore, dissenting government backbenchers will most likely not influence the contents of a compromise solution. This does not, however, eliminate the need to compromise with opposition parties when the Bundesrat is not controlled by government parties. Thus, party loyalty is no complete substitute for the government's lack of agenda setting powers.

If we extend veto player theory to include motives other than policy, timetable control becomes a relevant resource for veto players in interaction with non-veto players (cell III in Table 1). As demonstrated above, the government does not enjoy 
any prerogatives in setting the timetable agenda in the Bundestag, and the control by the parliamentary majority is also limited.

The second analytical focus identified above studies agenda setting as a relevant aspect of executive legislative relations in the broader context of political competition. In this context, agenda setting among veto players takes place between the executive and 'its' parliamentary parties (cell II). Relevant institutional mechanisms include the combination of the vote on a bill with a vote of confidence and the limitations on individual members' rights in the Bundestag. The first mechanism has only been used once. It may have been relevant as a threat somewhat more often, but certainly is not a constantly dominant feature of the interaction between the government and 'its' PPGs. The second mechanism restricts to an extent the ability of minorities within a PPG to hurt their party by introducing bills and offering controversial amendments. Overall, both mechanisms do not seem to play a major role due to the high unity displayed by parliamentary parties in Germany. ${ }^{90}$ All this should not be taken as evidence for streamlined PPGs, though. It is clear from qualitative research that parliamentary parties, specialised policy groups within PPGs, and party representatives in parliamentary committees do influence the positions taken by the government and the final outputs of the legislative process. ${ }^{91}$

Finally, we can study agenda setting between veto players and non-veto players with regard to executive legislative relations (cell IV in Table 1). Here, the empirical analysis of Bundestag rules found an extremely weak position of the executive branch and severe restrictions on agenda control by parliamentary majorities. Taking agenda setting as an indicator, the German government cannot be considered dominant vis-àvis the Bundestag.

\section{CONCLUSION}

Government agenda-setting rights are an important topic both with regard to direct policy effects in the context of spatial models and more broadly in the analysis of executive legislative relations. These analytical foci, both of which can be identified in the discussion of agenda setting in Tsebelis' veto player theory, should be analysed separately. As a second dimension, it is important to distinguish studies analysing only agenda setting among veto players from those including non-veto players as well. Combining these dimensions leads to four different theoretical perspectives on agenda setting with one overarching research question each.

These distinctions are not only relevant for classifying existing studies, they also point to some problems with respect to empirical indicators employed. Often, indicators capturing agenda setting between veto players and non-veto players are used to operationalise agenda setting among veto players. This impedes empirical tests of theoretical arguments about the policy effects of agenda setting. Thus, we have to find indicators that speak directly to the theoretically relevant processes among veto players. Agenda setting within cabinets and mechanisms for resolving inter-chamber differences in bicameral systems are identified as promising in this context. Mechanisms of agenda setting involving veto players and non-veto players are useful as indicators for executive dominance and may offer an interesting institutional alternative to the behavioural proxies currently used in the literature. 
Empirically, this article focused on agenda setting rules in the Bundestag. The most interesting finding is the extremely weak institutional position of the government. The executive has almost no formal prerogatives with regard to controlling the content of bills and the conduct of parliamentary business. Even when rights of parliamentary majorities are treated as government rights, the control of the governing parties is very limited as the rules of procedure grant minorities various opportunities to influence both the voting agenda and the timetable agenda. In practice, the relative institutional balance between the governing majority and the opposition has led to a consensual style of organising business in the Bundestag.

The weak role of the government can be explained by historic factors and analytical arguments about the party system and the institutional structure of lawmaking in Germany. The institutional legacy of earlier rules of procedure developed under the nineteenth century constitutional monarchy, the fear of a very strong executive after 1945 , and the prevalent self-perception of parliamentarians clarify why the Basic Law and the first Bundestag rules of procedure provide for a government without major agenda setting rights. Analytical arguments about characteristics of the party system, the government format, and the importance of the Bundesrat as additional veto player explain why no government since has pushed for stronger agenda setting prerogatives.

Overall, the investigation of agenda setting in the Bundestag reinforces the general characterisation of the German political system as a democracy with multiple veto players and strong consensus elements. Consensus beyond the narrow range of governing parties is required for changing policy in the 'grand coalition state'.92 Neither the executive branch nor the governing parties in parliament are able to unilaterally control business in the Bundestag and, more broadly, policy-making in Germany.

\section{NOTES}

An earlier version of this article was presented to the workshop 'The Role of Governments in Legislative Agenda Setting' at the ECPR Joint Session of Workshops in Granada, April 2005. The author thanks the workshop directors Bjorn Erik Rasch and George Tsebelis as well as all workshop participants for valuable comments and suggestions. The author is also grateful for additional comments and suggestions by Erin Ackerman, Matthias Lehnert, Bernhard Miller, Wolfgang C. Müller, Thomas Saalfeld, and two anonymous reviewers.

1. R.D. McKelvey, 'Intransitivities in Multidimensional Voting Models and Some Implications for Agenda Control', Journal of Economic Theory, 12/3 (1976), pp.472 82; N. Schofield, 'Instability of Simple Dynamic Games', Review of Economic Studies, 45/3 (1978), pp.575 94.

2. G. Tsebelis, Veto Players: How Political Institutions Work (Princeton: Princeton University Press, 2002).

3. J.D. Huber, Rationalizing Parliament. Legislative Institutions and Party Politics in France (Cambridge: Cambridge University Press, 1996).

4. But see H. Döring, 'Worauf gründet sich die Agenda Setzer Macht der Regierung?', in S. Ganghof and P. Manow (eds.), Mechanismen der Politik (Frankfurt: Campus, 2005), pp.109 48; G. Loewenberg, 'Agenda Setting in the German Bundestag. Origins and Consequences of Party Dominance', Journal of Legislative Studies, 9/3 (2003), pp.17 31.

5. H. Döring, 'Time as a Scarce Resource: Government Control of the Agenda', in H. Döring (ed.), Par liaments and Majority Rule in Western Europe (Frankfurt: Campus, 1995), pp.223 46; Tsebelis, Veto Players, table 4.1 .

6. Even though this article is theoretically grounded in rational choice theory and uses some of its termi nology, the descriptive information and the historical explanation offered should be useful to scholars from other theoretical backgrounds as well. There are certainly additional dimensions that could be 
analysed. These two were chosen because they seem most relevant to clarify the debate on agenda setting sparked by Tsebelis' veto player theory.

7. Agenda setting also figures prominently in game theoretic models of bargaining in legislatures; see e.g., D.P. Baron and J.A. Ferejohn, 'Bargaining in Legislatures', American Political Science Review, 83/4 (1989), pp.1181 1206. This literature is not dealt with here.

8. This argument extends the classic agenda setter model developed by Romer and Rosenthal; T. Romer and H. Rosenthal, 'Political Resource Allocation, Controlled Agendas, and the Status Quo', Public Choice, 33/4 (1978), pp.27 44.

9. Tsebelis, Veto Players, pp.33 7.

10. Ibid., p.111.

11. Ibid., pp.109 14 and 219 20; see also M.S. Shugart and J.M. Carey, Presidents and Assemblies. Con stitutional Design and Electoral Dynamics (Cambridge: Cambridge University Press, 1992).

12. A. Lijphart, Patterns of Democracy. Government Forms and Performance in Thirty six Countries (New Haven: Yale University Press, 1999).

13. Romer and Rosenthal, 'Political Resource Allocation, Controlled Agendas, and the Status Quo'; Tsebe lis, Veto Players, ch.1.

14. M. Laver and K.A. Shepsle (eds.), Cabinet Ministers and Parliamentary Government (Cambridge: Cambridge University Press, 1994); K. Strøm and W.C. Müller, 'The Keys to Togetherness. Coali tion Agreements in Parliamentary Democracies', Journal of Legislative Studies, 5/3 4 (1999), pp.255 82.

15. For example, K. Strøm, W.C. Müller and T. Bergman (eds.), Delegation and Accountability in Parlia mentary Democracies (Oxford: Oxford University Press, 2003); D. Diermeier and T.J. Feddersen, 'Cohesion in Legislatures and the Vote of Confidence Procedure', American Political Science Review, 92/3 (1998), pp.611 21.

16. Tsebelis, Veto Players, ch.4; see also G.B. Powell, Elections as Instruments of Democracy: Majoritar ian and Proportional Visions (New Haven: Yale University Press, 2000).

17. Tsebelis, Veto Players, pp.78 81, 94.

18. S. Ganghof, 'Promises and Pitfalls of Veto Player Analysis', Swiss Political Science Review, 9/2 (2003), pp.1 25; see also Döring, 'Time as a Scarce Resource'.

19. Otherwise typological studies in the tradition of Lijphart or Powell would hardly be useful.

20. A. King, 'Modes of Executive legislative Relations: Great Britain, France, and West Germany', Leg islative Studies Quarterly, 1/1 (1976), pp.11 34.

21. We can conceptualise these rights to be controlled by a collective party leadership consisting of govern ment members, leaders of the government parties in parliament, and the leadership of the extra parliamentary party organisations. Government members play an important role in this collective leadership group. The leadership internalises the costs for coordinating members' behaviour in parliament and other arenas and induces unity in voting by means of positive incentives and (at least the threat of) negative sanctions. Members of the party leadership are rewarded for their services both through office benefits (within parliament and, for governing parties, in the cabinet) and in policy terms because they exercise disproportionately strong influence on the policy position taken by their party; see G.W. Cox and M.D. McCubbins, Legislative Leviathan. Party Government in the House (Berkeley: University of California Press, 1993); U. Sieberer, 'Party Unity in Parliamentary Democracies. A Comparative Analysis', Journal of Legislative Studies (forthcoming).

22. Relevant instruments of agenda setting in committees and between committees and the plenary are dis cussed in Döring, 'Time as a Scarce Resource'; I. Mattson and K. Strøm, 'Parliamentary Committees', in H. Döring (ed.), Parliaments and Majority Rule in Western Europe (Frankfurt: Campus, 1995), pp.249 307; I. Mattson, 'Private Members' Initiatives and Amendments', in H. Döring (ed.), Parlia ments and Majority Rule in Western Europe (Frankfurt: Campus, 1995), pp.448 87; E. Damgaard, 'How Parties Control Committee Members', in H. Döring (ed.), Parliaments and Majority Rule in Western Europe (Frankfurt: Campus, 1995), pp.308 25.

23. Döring, 'Worauf gründet sich die Agenda Setzer Macht der Regierung?'

24. On the relationship between public opinion and parliamentary activity in the Bundestag see F. Brettschneider, Öffentliche Meinung und Politik. Eine Empirische Studie zur Responsivität des Deutschen Bundestages (Opladen: Westdeutscher Verlag, 1995) and K.v. Beyme, Der Gesetzgeber. Der Bundestag als Entscheidungszentrum (Opladen: Westdeutscher Verlag, 1997), pp.73 91.

25. Tsebelis, Veto Players, chs.4, 7.

26. In addition to these two classes of agenda setting rights, rules on voting procedures such as the order of voting, the voting procedure used and vote counting rules may shift the balance in favour of the govern ment in legislative decision making; see B.E. Rasch, 'Parliamentary Voting Procedures', in H. Döring (ed.), Parliaments and Majority Rule in Western Europe (Frankfurt: Campus, 1995), pp.488 527; B.E. Rasch, 'Parliamentary Floor Voting Procedures and Agenda Setting in Europe', Legislative Studies 
Quarterly, 25/1 (2000), pp.3 23. These rules are not discussed here, as they do not display particularly interesting aspects in the German case.

27. T. König, 'Bicameralism and Party Politics in Germany. An Empirical Social Choice Analysis', Politi cal Studies, $49 / 3$ (2001), pp.411 37; T. Bräuninger and T. König, 'The Checks and Balances of Party Federalism. German Federal Government in a Divided Legislature', European Journal of Political Research, 36/2 (1999), pp.207 35. The percentage of bills requiring approval by the Bundesrat has been constantly above 50 per cent since 1969 and reached a maximum of 60.6 per cent from 1983 87. Qualitatively, very few important bills do not require the consent of the Bundestag. The numbers are from P. Schindler, Datenhandbuch zur Geschichte des Deutschen Bundestages 1949 bis 1999 (Baden Baden: Nomos, 1999), pp.2430 32.

28. Opposition parties held a majority in the Bundesrat in the periods $197076,197882,199498$, and since 2002. The government held a majority in the years 198389 , temporarily in 1990 and 1998 99. During the remaining periods, state governments containing both government and opposition parties could tip the balance in the Bundesrat.

29. T. Saalfeld, 'The German Bundestag. Influence and Accountability in a Complex Environment', in P. Norton (ed.), Parliaments and Governments in Western Europe (London: Frank Cass, 1998), pp.44 72; W. Zeh, 'Das Ausschußsystem im Bundestag', in H. Schneider and W. Zeh (eds.), Parla mentsrecht und Parlamentspraxis in der Bundesrepublik Deutschland (Berlin: De Gruyter, 1989), pp.1087 1102.

30. S.S. Schüttemeyer, 'Hierarchy and Efficiency in the Bundestag: The German Answer to Institutionaliz ing Parliament', in G.W. Copeland and S.C. Patterson (eds.), Parliaments in the Modern World. Changing Institutions (Ann Arbor: University of Michigan Press, 1994), pp.29 58; Loewenberg, 'Agenda Setting in the German Bundestag'.

31. Loewenberg, 'Agenda Setting in the German Bundestag'; H. Roll, 'Der Ältestenrat', in H. Schneider and W. Zeh (eds.), Parlamentsrecht und Parlamentspraxis in der Bundesrepublik Deutschland (Berlin: De Gruyter, 1989), pp.809 28.

32. Loewenberg, 'Agenda Setting in the German Bundestag'; W. Zeh, 'Altersschichten in der Geschäfts ordnung des Deutschen Bundestages', Zeitschrift für Parlamentsfragen, $17 / 3$ (1986), pp.396 413 ; N. Lammert, 'Zur Geschäftsordnung. Notizen zur Entstehung und Bedeutung parlamentarischer Verfah rensregeln', in Deutscher Bundestag (ed.), Die Geschäftsordnungen deutscher Parlamente seit 1848 (Bonn: Deutscher Bundestag, 1986), pp.10 18.

33. Schindler, Datenhandbuch zur Geschichte des Deutschen Bundestages, pp.3094 3122.

34. N. Achterberg, Parlamentsrecht (Tübingen: J.C.B. Mohr, 1984); H. Roll, Geschäftsordnung des Deutschen Bundestages. Kommentar (Baden Baden: Nomos, 2001).

35. For example, the role of the opposition is not formally acknowledged in the rules and as will be dis cussed at length the executive branch plays almost no role in organising parliamentary business.

36. All non transient German cabinets after 1949 controlled a parliamentary majority; see T. Saalfeld, 'Germany. Stable Parties, Chancellor Democracy, and the Art of Informal Settlement', in W. C. Müller and K. Strøm (eds.), Coalition Governments in Western Europe (Oxford: Oxford University Press, 2000), pp.32 85.

37. To cite just one recent example, a study of fiscal policy during the first red green Schröder government (1998 2002) links the change from traditional social democratic to more liberal, supply oriented pol icies to agenda setting powers of the chancellor himself and the change in the office of finance minister; see R. Zohlnhöfer, 'Rot grüne Finanzpolitik zwischen traditioneller Sozialdemokratie und neuer Mitte', in C. Egle, T. Ostheim and R. Zohlnhöfer (eds.), Das rot grüne Projekt. Eine Bilanz der Regierung Schröder 19982002 (Wiesbaden: Westdeutscher Verlag, 2003), pp.194 214.

38. Art. 34, 37 of the French Constitution. France is treated as a parliamentary democracy because it fulfils the defining feature of parliamentary government, that is, the accountability of the prime minister to par liament which can vote the government out of office for political reasons (see W.C. Müller, T. Bergman and K. Strøm, 'Parliamentary Democracy: Promise and Problems', in K. Strøm, W.C. Müller and T. Bergman (eds.), Delegation and Accountability in Parliamentary Democracies (Oxford: Oxford Uni versity Press, 2003), pp.3 32). Executive decrees are also important agenda setting instruments of pre sidential governments in Latin America, see Shugart and Carey, Presidents and Assemblies; J.M. Carey and M.S. Shugart (eds.), Executive Decree Authority, (Cambridge: Cambridge University Press, 1998).

39. H.D. Jarass and B. Pieroth, Grundgesetz für die Bundesrepublik Deutschland. Kommentar (München: C.H.Beck, 6. ed., 2002), pp.516 20.

40. Negative government agenda control existed in the French Third and Fourth Republic, but has been very rare otherwise; see Döring, 'Worauf gründet sich die Agenda Setzer Macht der Regierung?', p.111.

41. On legislative initiatives see Döring, 'Time as a Scarce Resource'; Mattson, 'Private Members' Initiat ives and Amendments'; on last offer authority see W.B. Heller, 'Making Policy Stick: Why the Govern ment Gets What It Wants in Multiparty Parliaments', American Journal of Political Science, 45/4 
(2001), pp.780 98; B.R. Weingast, 'Fighting Fire with Fire. Amending Activity and Institutional Reform in the Postreform Congress', in R.H. Davidson (ed.), The Postreform Congress (New York: St. Martin's Press, 1992), pp.142 68.

42. From 1949 to $1994,59.0$ per cent of all bills were initiated by the government, 34.4 per cent by groups of the Bundestag and 6.6 per cent by the Bundesrat. The relatively high number of initiatives from parlia ment and their reasonably high success rate do not necessarily indicate a strong independent role of par liamentary actors as initiators of legislation. Instead, many of these initiatives are introduced by the governing parties in order to save time because government initiatives have to be dealt with in the Bun desrat prior to the first reading in the Bundestag; see W. Ismayr, Der Deutsche Bundestag im politischen System der Bundesrepublik Deutschland (Opladen: Leske + Budrich, 2000), pp.240, 245.

43. During the third reading, amendments can only be proposed by PPGs/5 per cent and may only refer to clauses amended during the second reading; $§ 82$ I, 85 I GOBT; R. Kabel, 'Die Behandlung der Anträge im Bundestag. Rechte, Formen und Verfahren’, in H. Schneider and W. Zeh (eds.), Parlamentsrecht und Parlamentspraxis in der Bundesrepublik Deutschland (Berlin: De Gruyter, 1989), pp.883 916, pp.902 3.

44. From 1972 to $1990,62.2$ per cent of all bills were changed during the committee stage; see Schindler, Datenhandbuch zur Geschichte des Deutschen Bundestages, pp.2396 97.

45. K.v. Beyme, Der Gesetzgeber, p.202; Ismayr, Der Deutsche Bundestag im politischen System der Bun desrepublik Deutschland, pp.275 83; H. Schulze Fielitz, Theorie und Praxis parlamentarischer Gesetzgebung besonders des 9. Deutschen Bundestages 19801983 (Berlin: Duncker\&Humblot, 1988), pp.304 48 .

46. Mattson, 'Private Members' Inititatives and Amendments'. Mattson discusses additional formal require ments attached to private member initiatives and amendments in European parliaments. The only one relevant in the German case is the restriction of initiatives to groups of 5 per cent of all deputies or PPGs and the limits on individual amendments during the third reading (see above).

47. Mattson, 'Private Members' Inititatives and Amendments', p.476.

48. W. Rudzio, Das politische System der Bundesrepublik Deutschland (Opladen: Leske + Budrich, 6. ed., 2003), p.280.

49. Roll, Geschäftsordnung des Deutschen Bundestages, pp.135 37.

50. Kabel, 'Die Behandlung der Anträge im Bundestag. Rechte, Formen und Verfahren', p.901.

51. Ibid., pp.901 2 .

52. J.D. Huber, 'The Vote of Confidence in Parliamentary Democracies', American Political Science Review, 90/2 (1996), pp.269 82; see also Diermeier and Feddersen, 'Cohesion in Legislatures and the Vote of Confidence Procedure'.

53. Heller, 'Making Policy Stick', pp.782 3.

54. Thus, a government could win the vote on a bill by a simple majority and still lose the vote of confi dence. Huber's description of the German procedure is wrong when he claims that the government wins the vote unless an absolute majority vote against it as in France; see Huber, 'The Vote of Confi dence in Parliamentary Democracies', p.271.

55. H. Döring and C. Hönnige, "Vote of Confidence and "Gesetzgebungsnotstand": Two Tooth and Claw less Tigers of Governmental Agenda Control', German Politics, forthcoming.

56. In addition to being an agenda setting instrument, the vote of confidence also offers the only chance for an early dissolution of the Bundestag. Chancellors Brandt (1972), Kohl (1982), and Schröder (2005) deliberately lost a vote of confidence not tied to any particular bill in order to obtain early elections.

57. W.J. Patzelt, 'Chancellor Schröder's Approach to Political and Legislative Leadership', German Poli tics 13/2 (2004), pp.268 99, pp.294 5.

58. After losing a vote of confidence, the government can ask the President with the consent of the Bundes rat to declare a legislative emergency for a period of six months, during which a bill becomes law solely with the consent of the Bundesrat. While this procedure allows a government without majority in the Bundestag to legislate, the government is still limited by the President's willingness to declare a legislative emergency and by the necessary consent of the Bundesrat; see Döring and Hönnige, 'Vote of Confidence and "Gesetzgebungsnotstand".

59. Döring, 'Time as a Scarce Resource'.

60. At the beginning of each legislative period, the PPGs agree on how to divide speaking time in proportion to the percentage of seats held by each party. This allotment is stable over the entire legislative period; see Roll, Geschäftsordnung des Deutschen Bundestages, p.51; H.J. Schreiner, 'Die Berliner Stunde Funktionsweise und Erfahrungen. Zur Redeordnung des Deutschen Bundestages', Zeitschrift für Parlamentsfragen, 36/3 (2005), pp.573 88.

61. In order to avoid surprise proposals, motions to amend (but not to shorten) the agenda have to be filed with the president of the Bundestag on the day before the sitting.

62. Döring, 'Worauf gründet sich die Agenda Setzer Macht der Regierung?'. 
63. Loewenberg, 'Agenda Setting in the German Bundestag'; Roll, Geschäftsordnung des Deutschen Bundestages, pp.37 9. Other minority rights include the right to demand a committee report about the progress on a bill after ten weeks and debate the report ( $\$ 62$ II GOBT) and the right to demand a debate on an interpellation (Große Anfrage, $\$ 102$ GOBT).

64. R. Kabel, 'Die Entstehung der Tagesordnung durch interfraktionelle Vereinbarungen', in H. Roll (ed.), Plenarsitzungen des Deutschen Bundestages (Berlin: Duncker und Humblot, 1982), pp.29 43; Roll, 'Der Ältestenrat', pp.816 8.

65. The number of motions to change the agenda was constantly below ten over the four year legislative period prior to 1983. Between 1983 and 1998, their numbers rose to between 20 and 33. It is interes ting to note that both the Greens and the post socialist PDS introduced disproportionately many such motions during their first sessions in the Bundestag. At least the Greens have adjusted to the level of the older PPGs since 1990; Loewenberg, 'Agenda Setting in the German Bundestag, tables 1 and 2.

66. Mattson, 'Private Members' Inititatives and Amendments', p.476; Döring, 'Time as a Scarce Resource'.

67. Kabel, 'Die Entstehung der Tagesordnung durch interfraktionelle Vereinbarungen', p. 40.

68. One should keep in mind that the mere requirement of parliamentary approval for an executive decree is a limitation of government power rather than a sign of government prerogatives.

69. G.W. Cox, The Efficient Secret. The Cabinet and the Development of Political Parties in Victorian England (Cambridge: Cambridge University Press, 1987).

70. Huber, Rationalizing Parliament.

71. V. Otto, Das Staatsverständnis des Parlamentarischen Rates. Ein Beitrag zur Entstehungsgeschichte des Grundgesetzes für die Bundesrepublik Deutschland (Düsseldorf: Rheinisch Bergische Druckerei und Verlagsgesellschaft, 1971), pp.95 7, 100 2. The constituent assembly even discussed a govern ment elected by, but not accountable to the Bundestag (the Swiss model) as an alternative to the parliamentary system. This indicates that even parliamentary government itself was not completely uncontroversial.

72. D. Herzog, et al., Abgeordnete und Bürger. Ergebnisse einer Befragung der Mitglieder des 11. Deutschen Bundestages und der Bevölkerung (Opladen: Westdeutscher Verlag, 1990), pp.101 9. Very similar results were found in another study on the self perception of members of the Bundestag, the state legislatures, and the European Parliament; W.J. Patzelt, 'Deutschlands Abgeordnete. Profil eines Berufsstands, der weit besser ist als sein Ruf’, Zeitschrift für Parlamentsfragen, $27 / 3$ (1996), pp.462 502 .

73. Keep in mind that one of the decisive steps in installing the Nazi dictatorship was a law delegating all legislative power to the government (the Ermächtigungsgesetz of 23 March 1933).

74. K.F. Fromme, Von der Weimarer Verfassung zum Bonner Grundgesetz (Berlin: Duncker und Humblot, 3rd ed., 1999).

75. Loewenberg asks the same question though with a more limited focus on what this article refers to as the control of the timetable agenda. He explains the absence of centralising tendencies with the already strong institutionalisation of the Bundestag as an independent institution and the interests of parliamen tary party leaders in defending the decentralised procedures inherited from before the parliamentarisa tion of the German political system. Note that this explanation is consistent with the historic argument presented above about the importance of the self perception of parliamentary actors; Loewenberg, 'Agenda Setting in the German Bundestag'.

76. T. Saalfeld, 'The German Party System Continuity and Change', German Politics, 11/3 (2002), pp.99 130.

77. T. Saalfeld, Parteisoldaten und Rebellen. Fraktionen im Deutschen Bundestag 19491990 (Opladen: Leske + Budrich, 1995). Party unity in the Bundestag is hard to measure because data on individual voting behaviour is only available for a small minority of votes. Most proposals are voted on by anon ymous procedures such as voice votes, show of hands, or rising in places.

78. König, 'Bicameralism and Party Politics in Germany'.

79. M. Laver and K.A. Shepsle, Making and Breaking Governments (Cambridge: Cambridge University Press, 1996).

80. Huber, 'The Vote of Confidence in Parliamentary Democracies'.

81. Tsebelis, Veto Players, pp.106 9.

82. For empirical attempts see Laver and Shepsle, Cabinet Ministers and Parliamentary Government; Strøm and Müller, 'The Keys to Togetherness'.

83. K. Niclauß, Kanzlerdemokratie. Regierungsführung von Konrad Adenauer bis Gerhard Schröder (Paderborn: Schöningh, 2004).

84. Rudzio, Das politische System der Bundesrepublik Deutschland, pp.284 90; K. Korte and M. Fröhlich, Politik und Regieren in Deutschland. Strukturen, Prozesse und Entscheidungen (Paderborn: Schöningh, 2004), pp.79 101. 
85. Saalfeld, 'Germany. Stable Parties, Chancellor Democracy, and the Art of Informal Settlement', pp.51 65.

86. F. Müller Rommel, 'The Role of German Ministers in Cabinet Decision Making', in M. Laver and K.A. Shepsle (eds.), Cabinet Ministers and Parliamentary Government (Cambridge: Cambridge University Press, 1994), pp.150 68.

87. G. Tsebelis and J. Money, Bicameralism (Cambridge: Cambridge University Press, 1997), ch.8.

88. The only formal regulations refer to the quorum for decision ( 12 of the 32 members need to be present) and the decision rule (majority of the members present) ( $\$ 7,8 \mathrm{GO}$ VermA).

89. M. Dietlein, 'Vermittlung zwischen Bundestag und Bundesrat', in H. Schneider and W. Zeh (eds.), Par lamentsrecht und Parlamentspraxis in der Bundesrepublik Deutschland (Berlin: De Gruyter, 1989), pp.1565 78, pp.1574 5 .

90. It is unclear whether unity is induced by these and other institutional rules such as rewards and sanctions at the disposal of the PPG leadership or results from shared interests and intra party socialisation; see Saalfeld, Parteisoldaten und Rebellen.

91. K.v. Beyme, Der Gesetzgeber; S.S. Schüttemeyer, Fraktionen im Deutschen Bundestag 19491997. Empirische Befunde und theoretische Folgerungen (Opladen: Westdeutscher Verlag, 1998).

92. M.G. Schmidt, 'Germany. The Grand Coalition State', in J.M. Colomer (ed.), Political Institutions in Europe (London: Routledge, 2002), pp.57 93. 